\title{
PKM Pemberdayaan Hasil Kreativitas Santri untuk Meningkatkan Perekonomian Pesantren di Masa Pandemi Covid 19
}

\author{
Sofian Syaiful Rizal ${ }^{1}$, Izah Afkarina ${ }^{2}$, Niroh Qonita Tillah ${ }^{3}$, Ayu Asari ${ }^{4}$, \\ Halimatus Sya'diyah ${ }^{5}$, Istiqomah Vidyanti ${ }^{6}$, Widya Anggraini ${ }^{7}$
}

Universitas Nurul Jadid, Probolinggo 1,2,3,4,5,6,7

\{sofiansyaifulrizal@unuja.ac.id\}

Submission: 28/09/2021 Received: 29/12/2021 Published: 31/12/2021

\section{Keywords: \\ Empowerment, Student \\ Creativity, economy islamic boarding school}

Katakunci:

Pemberdayaan, Kreatifitas Santri, Perekonomian Pesantren

\begin{abstract}
The results of the creativity of students have various types according to each skill possessed by students under the auspices of the Az-zainiyah PP Regional Skills Office. Nurul Jadid. Even during a pandemic, students still produce creativity such as producing bags with hand embroidery, producing flower pots with unused towels in the trash, producing beautiful roses with used bottles, producing beautiful calligraphy writing by sticking them on glass etc. Of course, with the creativity of these students, they need assistance and training/workshops to be more focused and useful, especially in improving the pesantren economy with the creativity of students during the COVID-19 pandemic, therefore this community service provides productive entrepreneurial competencies for students. The partner of service activities is PP. Nurul Jadid in the Az-Zainiyah Region, which has an enje mart (Islamic boarding school) cooperation with the santri skills office. The method of implementing community service activities is socialization/workshop, practice, mentoring. socialization about the prospects for the creativity of students by training their skills in improving the economic management of pesantren during the pandemic. This activity is expected to be useful in improving the economy of the pesantren and training students' skills in entrepreneurship with the results of their own creativity with good management.
\end{abstract}

Abstrak. Hasil kreatifitas santri mempunyai beraneka ragam jenis sesuai masing-masing skill yang di miliki oleh santri dibawah naungan kantor keterampilan Wilayah Az-zainiyah PP. Nurul Jadid. disaat pandemipun santri tetap menghasilkan kreatifitas semisal menghasilkan tas dengan sulaman tangan, menghasilkan pot bunga dengan handuk yang tak terpakai disampah, menghasilkan bunga mawar cantik dengan botol bekas, menghasilkan tulisan kaligrafi indah dengan menempelkan pada kaca dll. tentunya dengan hasil kreatifitas santri ini butuh pendampingan dan pelatihan/workshop agar lebih terarah dan bermanfaat hususnya dalam peningkatan perekonomian pesantren dengan hasil kreatifitas santri dimasa pandemi covid 19 oleh karena itu pengabdian masyarakat ini memberikan kompetensi wirausaha 
produktif bagi santri. Mitra kegiatan pengabdian adalah PP. Nurul Jadid Wilayah Az-Zainiyah yang telah memiliki kerja sama enje mart (koperasi pesantren) dengan kantor keterampilan santri. Metode penelitian menggunakan metode deskriptif kualitatif yakni pelaksanaan kegiatan pengabdian berupa sosialisasi/workshop, praktek, pendampingan. sosialisasi mengenai prospek hasil kreatifitas santri dengan melatih skill mereka dalam peningkatan menegement perekonomian pesantren di masa pandemi. Kegiatan ini diharapkan dapat bermanfaat dalam meningkatkan perekonomian pesantren dan melatih skill santri dalam berwirausaha dengan hasil kreatifitas mereka sendiri dengan menejemen yang baik.

\section{Pendahuluan}

Kerajinan merupakan salah satu bagian dari seni rupa yang sudah ada sejak lama. Kita diperkenalkan dengan kerajinan dan seni rupa sejak dimulainya masuk ke jenjang pendidikan. Kerajinan sendiri diminati oleh semua kalangan dan tidak dibatasi oleh usia ataupun jenis kelamin. Saat ini kerajinan sudah sangat berkembang dan mengakibatkan munculnya kerajinan modern. Sehingga terdapat dua macam kerajinan yang kita ketahui saat ini, ada Kerajinan Tradisional dan Kerajinan Modern. Kerajinan Tradisioanal sendiri itu kerajinan yang dilakukan turun-menurun secara sederhana oleh masyarakat setempat, seperti kerajinan batik, anyaman bambu, anyaman rotan, dan lain sebagainya. Sedangkan Kerajinan Modern itu kerajinan yang dilakukan secara modern menggunakan bahan bekas atau lainnya seperti tas dengan sulaman tangan, pot bunga dengan handuk yang tidak terpakai, Bunga mawar dengan botol bekas, tulisan tangan kaligrafi dengan menempelkan pada kaca dan lain sebagainya (Feriyadi, 2021).

Secara teori, kemandirian dalam berkreasi dalam kerajinan tangan dalam meningkatkan perekonomian di pondok pesantren dapat didefinisikan sebagai sikap yang memungkinkan seseorang untuk bertindak dan melakukan sesuatu atas dorongan sendiri dan untuk kebutuhannya sendiri tanpa bantuan dari orang lain, mampu berpikir dan bertindak kreatif dan penuh inisiatif, mampu mempengaruhi lingkungan, mempunyai rasa percaya diri dan memperoleh kepuasan dari usahanya tersebut. Selain itu, dalam kamus psikologi, kemandirian berasal dari kata independence yang diartikan sebagai suatu kondisi dimana seseorang tidak bergantung pada orang lain dalam menentukan keputusan yang disertai dengan sikap percaya diri. 
Kemandirian dalam berkreasi dalan kerajinan dan berkarya seni dalam meningkatkat perekonomian di pondok pesantren inilah yang juga diharapkan oleh para santri yang ada di Pondok Pesantren Nurul jaded di wilayah azzainiyah. Kemandirian tidak akan muncul begitu saja, kemandirian harus dilatih untuk membentuk jiwa santri yang mandiri dan itupun membutuhkan waktu dan proses yang tidak sebentar. Sebagaimana yang dikemukakan oleh (Martinis Yamin, 2013), bahwa kemandirian merupakan kemampuan hidup yang utama dan salah satu kebutuhan sejak awal usianya. Membentuk anak usia dini sebagai pribadi yang mandiri memerlukan proses yang dilakukan secara bertahap. Oleh sebab itu, untuk mewujudkan santri yang mandiri diperlukan wadah dan juga SDM (sumber daya manusia) yang mampu melatih, mampu membentuk dan mampu menularkan ide-ide atau gagasan-gagasan kepada santri sehingga nantinya santri-santri tersebut dapat tumbuh menjadi santri-santri berdikari, kreatif, inovatif dan tentunya mandiri.

Kantor keterampilan Pondok Pesantren Nurul Jadid wilayah AZ-Zainiyah adalah salah satu tempat santri dalam berkarya dengan potensi yang dimiliki oleh para santri. Namun hal tersebut belum ada workshop atau pelatihan khusus bagi santri yang mempunyai bakat. Sehingga perlu kiranya kami mahasiswa KKN dalam naungan LP3M UNUJA untuk memenej lebih tersistem dalam mengadakan workshop/pelatihan kerajinan bagi para santri yang memiliki minat yang bebeda-beda di wilayah azzainiyah pondok pesantren nurul jadid. Kerajinan tangan yang paling banyak di sukai oleh para santri ialah merajut tas dari benang. Pada dasarnya industri kerajinan santri memiliki berbagai macam ragam produk yang dapat diperdagangkan, tetapi tidak semua industri tersebut menjadi primadona unggul dalam pandangan semua santri di wilayah Az-Zainiyah, salah satunya adalah Tas rajut yang mungkin di saat ini di sukai oleh banyak kalangan santri (Fatmawati, 2019).

Wilayah Az-Zainiyah PP. Nurul Jadid Paiton lebih memilih menggunakan Kerajinan Modern karena lebih mudah dan sederhana untuk mempraktekkannya bagaimana cara mengolah daur ulang bekas lainnya menjadi hasil karya seni yang indah untuk diperlihatkan kepada semua khalayak di pesantren yang masih membuang botol-botol minuman bekas sembarangan, sebenarnya itu bisa membuahkan hasil karya yang sangat bagus dan bermanfaat untuk kepentingan diri sendiri dan pencemaran lingkungan. Dengan adanya kerajinan modern ini para santri bisa meluangkan 
waktunya untuk membuat kerajinan sesuai yang diinginkan atau sesuai yang dibutuhkan (Sari, 2021).

Kerajinan tangan modern ini banyak diminati oleh sebagian masyarakat di Indonesia, terutama di Wilayah Az-Zainiyah PP. Nurul Jadid Paiton. Karena kerajinannya sangat mudah untuk dibuatnya sesuai keinginan masingmasing. Sehingga menarik perhatian para santri sebagai hobby/kegemaran jika ada waktu luang. Selain itu, kerajinan tangan ini dapat dijadikan sebagai peningkatan perekonomian pesantren dengan hasil kreatifitas santri yang berbeda-beda. Tetapi kebanyakan dari santri disana tidak tahu bagaimana cara untuk menjual hasil karyanya dengan mendapatkan keuntungan sehingga mereka bisa mengumpulkan uang yang didapatkan dari hasil kerajinannya untuk ditabung. Dengan adanya pembangunan sarana retail atau tempat yang dapat menampung dan menjual hasil karya para santri dengan baik. Mereka dapat menaruh hasil karyanya ditempat kerajinan tersebut dengan memajang kerajinan yang sudah dibuat dengan berbagai macam. Kemudian kerajinannya ditampilkan di acara workshop sekolah agar memotivasi para anak sekolah ataupun para santri untuk mendaur ulang kembali bahan bekas yang tidak terpakai dengan menghasilakan karya sebagus dan seindah mungkin (Kholiq, 2021).

Barang atau bahan kerajinan umumnya berbentuk kecil dan halus, dari sini dapat dilihat bahwa kalau mau ngerancang tempat kerajinan itu harus sesuai dengan bentuk karkteristik dari barang yang akan dijual agar tidak merusak hasil kerajinan yang sudah dibuat, seperti wadah benang karena tidak boleh yang memiliki tekstur kasar agar serat benang tidak tersangkut. Untuk mencegah kerusakan kerajinan dibutuhkan kebersihan, aturan dalam memasuki tempat kerajinan tersebut dan kerapihan dalam menata atau merancang sebuah tempat kerajinan. Sehingga jika pembeli datang untuk melihat atau membeli itu tidak berebut atau kurang puas saat memasukinya (Muda'i, 2020).

Para santri juga harus bisa mengelola tempat kerajinan itu supaya tidak ada pembeli yang mengomentari buruk dengan keadaan tempat kerajinannya. Di tempat kerajinan sudah lengkap semua karena disana banyak macam hasil karya dari para santri yang ditaruh didepan etalase sesuai jenisnya. Disana diketahui bahwa kerajinan daur ulang bekasnya lumayan banyak daripada di wilayah pondok pesantren lainnya. Karena sudah jarang membuat lagi kerajinannya. Kemungkinan besar jika dilanjut semua 
tempat kerajinan dan para santri mempraktekkannya lagi yang ada di semua wilayah pondok pesantren Nurul Jadid Paiton pasti jauh lebih berkembang karya dari masing-masing anak.

Akan lebih keliatan karya para santri jika semua itu berjalan dengan baik dan tidak berhenti untuk mempraktekkannya lagi, sehingga tempat kerajinan jauh lebih banyak mempunyai keterampilan yang berbagai macam jenis dan bentuknya. Dan bisa menambah kemampuan dalam menciptakan pengetahuan baru yang berkesinambungan melalui tindakan kreatifitas dan inovatif para santri di Wilayah Az-Zaniyyah PP.Nurul Jadid Paiton. Jadi perlu adanya kemajuan dalam perkembangan keterampilan dari kemampuan para santri yang masih belum tau cara megolah daur ulang kertas menjadi barang yang bermanfaat untuk semua khalayak.

Kegiatan pengabdian ini dilakukan yang bertujuan untuk memberikan pengetahuan tentang kerajinan lebih dalam lagi kepada para santri atau anak sekolah yang masih belum mengenal kerajinan modern mendaur ulang dari bahan bekas yang tidak layak untuk dipakai sehingga tidak mencemarkan lingkungan sekitar atau mengurangi sampah plastic dan meningkatkan kualitas produk kerajinan yang sudah dibuat oleh para santri sebagai hasil karya yang sangat memuaskan.

\section{Metode}

Metode yang digunakan PKM pada pengabdian ini adalah metode deskriptif kualitatif. Penelitian deskriptif mengumpulkan data berdasarkan faktor-faktor yang menjadi pendukung objek penelitian, kemudian menganalisisnya untuk mencari peranannya (Arikunto, 2010). Penelitian kualitatif menurut Cresswel adalah penelitian yang menghasilkan penemuanpenemuan yang tidak dapat dicapai dengan menggunakan prosedur statistik atau cara-cara lain dari kuantifikasi (Rahmat, 2009).

Dalam penelitian ini peneliti mengkaji implementasi kerajinan kratifitas santri dalam meningkatkan skill dan kemampuan dalam mengembangkan bisnis perekonomian di wilayah Az-Zainiyah PP. Nurul Jadid sebagai bentuk pendidikan dalam kemandirian perekonomian para santriwati. Objek penelitian ini adalah PP. Nurul Jadid Wilayah Az-Zainiyah yang perlu memiliki kerja sama dengan enje mart (koperasi pesantren). Penelitian ini dilaksanakan pada Hari Rabu tanggal 10 februari 2021 berlokasi di wilayah az-zainiyah pondok pesantren nurul jadid paiton probolinggo. Pelaksanaan 
dimulai pada pukul 09.00-11.45 wib, dengan waktu yang diperlukan sekitar 23 jam setiap pertemuannya. Analisis data dalam penelitian ini dilakukan menggunakan metode deskriptif kualitatif dengan teknik Observasi, Pendampingan, Wawancara dan dokumentasi. Dengan mengumpulkan dan menganalisis data-data tersebut, penulis mendeskripsikan dan menyimpulkan pemecahan permasalahan pemberdayaan kreatifitas santri melalui pengembangan usaha ekonomi kreatif serta hubungannya dengan penguatan jiwa entrepreneurship santri.

\section{Pembahasan}

Menurut KBBI (2014) kerajinan adalah barang yang dihasilkan melalui keterampilan tangan (seperti menghasilkan tas dengan sulaman tangan, menghasilkan pot bunga dengan handuk yang tak terpakai disampah, menghasilkan bunga mawar cantik dengan botol bekas, menghasilkan tulisan kaligrafi indah dengan menempelkan pada kaca dan sebagainya); barangbarang sederhana, biasanya mengandung unsur seni; dapat pula didefinisikan sebagai usaha kecil-kecilan yang dikerjakan di rumah. Sementara itu, kerajinan tangan adalah kegiatan membuat barang-barang sederhana dengan menggunakan tangan.

Kegiatan pembinaan masyarakat yang dilaksanakan di wilayah azzainiyah pondok pesantren nurul jadid Langkah ini dimulai dengan pemberian ilmu pengetahuan mengenai proses pembuatan kerajinan tangan dari proses awal hingga selesai terbentuk dengan indah. Antusias para santriwati pada kegiatan ini sangat baik, dimana jumlah kehadiran mencapai 95\%. Materi yang disampaikan berkaitan dengan pembuatan kerajinan tangan dari berbagai macam kerajinan sesuai bakat dan minat santriwati.

Berdasarkan pengamatan langsung selama kegiatan pengabdian masyarakat di wilayah az-zainiyah ini ternyata banyak dari santri wati yang memahami dengan cepat materi yang telah disampaikan kemudian di praktekkan dan antusias para santriwati untuk membuat kerajinan menghasilkan tas dengan sulaman tangan, menghasilkan pot bunga dengan handuk yang tak terpakai disampah berdasarkan kreativitas mereka masingmasing. Adapun manfaat yang didapat dari kegiatan ini adalah: 
1. Memotivasi para santriwati untuk kreatif dalam memanfaatkan kreatifitas kerajinan tangan yang dimiliki oleh satriti dengan diadakannya workshop/pelatihan khusus.

2. Meningkatkan nilai tambah wawasan ilmu keterampilan khusus kerajinan tangan dalam berkreativitas dengan dibekali pelatihan berupa workshop.

3. Mengembangkan usaha dalam kerajinan tangan santriwati untuk meningkatkan perekonomian di masa covid 19

Melalui kreativitas dalam pembuatan kerajinan tangan diharapkan akan dihasilkan produk-produk yang bernilai jual tinggi. Menurut (Sari \& Wadji, 2017) kreativitas adalah kemampuan untuk membuat sesuatu yang baru dan berbeda entah sifatnya masih imajiner (gagasan) atau sudah diekspresikan dalam bentuk suatu karya. Kreativitas dapat berbentuk produk seni, kesusasteraan, produk ilmiah atau mungkin bersifat prosedural atau metodelogis. Menanamkan kemandirian dengan berwirausaha dapat mempengaruhi pola pikir sekaligus dapat mengembangkan kreativitas dan juga dapat memberdayakan masyarakat untuk bisa mandiri serta mampu membuka peluang usaha sendiri (Puratiningsih, 2017).

Berikut hasil dari kegiatan pengabdian kepada kantor kerajinan Pondok Pesantren Nurul Jadid Karanganyar, Paiton Probolinggo. Kegiatan ini diikuti oleh santri wilah AZ-Zainiyah yang mana dari kegiatan Ekstra kulikuler semua santri bisa meluapkan bakat atau pengetahuannya tentang sebuah kerajinan tangan, yang mana hal ini bisa meningkatkan inovasi produktifitas santri dalam masa pandemi covid 19 (Anwar, 2021). Adapun alternatif kerajinan tangan ini sudah banyak di sediakan oleh kantor keterampilan wilayah AzZainiyah, seperti contohnya tersedianya sebuah bahan kerajinan. Dalam kerajian tangan ini sudah banyak santri yang sukses dengan karyanya sehingga mereka juga bisa mendapat peluang baik dari karyanya sendiri yaitu dengan mempromusikan kepada teman melalui sebuah contoh hasil karyanya.

Pada saat ini, kerajinan tangan di Pondok Pesantren Nurul Jadid gerak usahanya sangatlah bisa membuktikan bahwa usaha kecil santri dalam bidang kerajinan tangan ini sangatlah luas manfaatnya. Mengingat luasnya kehidupan ekonomi suatu negara, sebuah keyakinan santri menghidupkan perusahan kerajinan kecil yang mampu mengurangi kegabutan santri sekaligus menghasilkan peluang yang besar dalam setiap karyanya (Sari, 
2021). Disamping itu, pada kegiatan ini dibahas pula produk kerajinan santri yang di hasilkan melaui bahan bekas seperti contohnya, botol minuman, plastik bekas, dll.

\section{a. Workshop pelatihan membuat produk kerajinan tangan}

Pada kegiatan ini, santri dilatih untuk lebih terampil dalam berinovasi membuat produk kerajinan tangan dengan mengadakan workshop mendatangkan para pakar yang ahli di bidang inovasi produk kerajinan tangan agar supaya skill santri lebih terasah dalam mengembangkan bakat minat mereka dengan lebih kreatif dengan adanya workshop dan pelatihan pada setiap kerajinan tangan yang diminati.

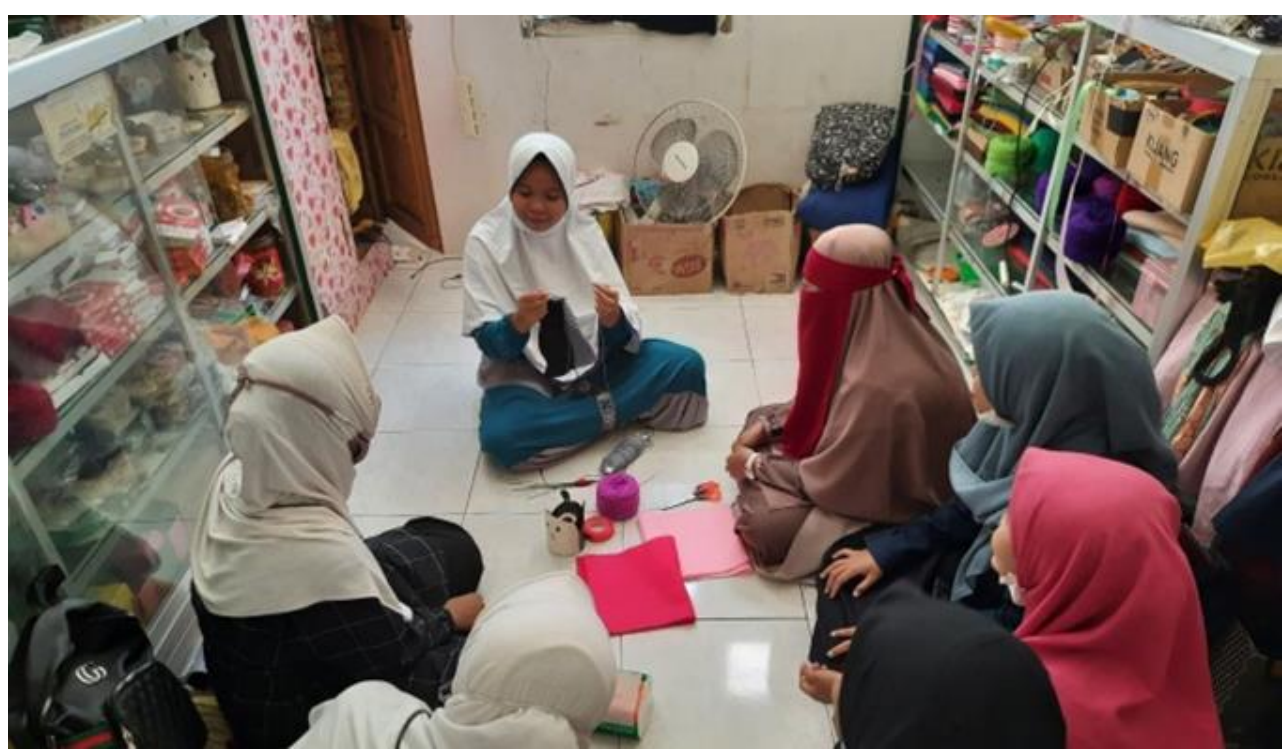

Gambar 1. Workshop pelatihan membuat produk kerajinan tangan

Kemudian setelah mengadakan pelatihan workshop inovasi maka para santri yang telah dilatih secara bersama-sama tim kerajinan santri dalam pengabdian ini banyak melakukan praktik pembuatan produk seperti tas rajut, vas bunga, bunga plastik, lampion dan hiasan kamar. 


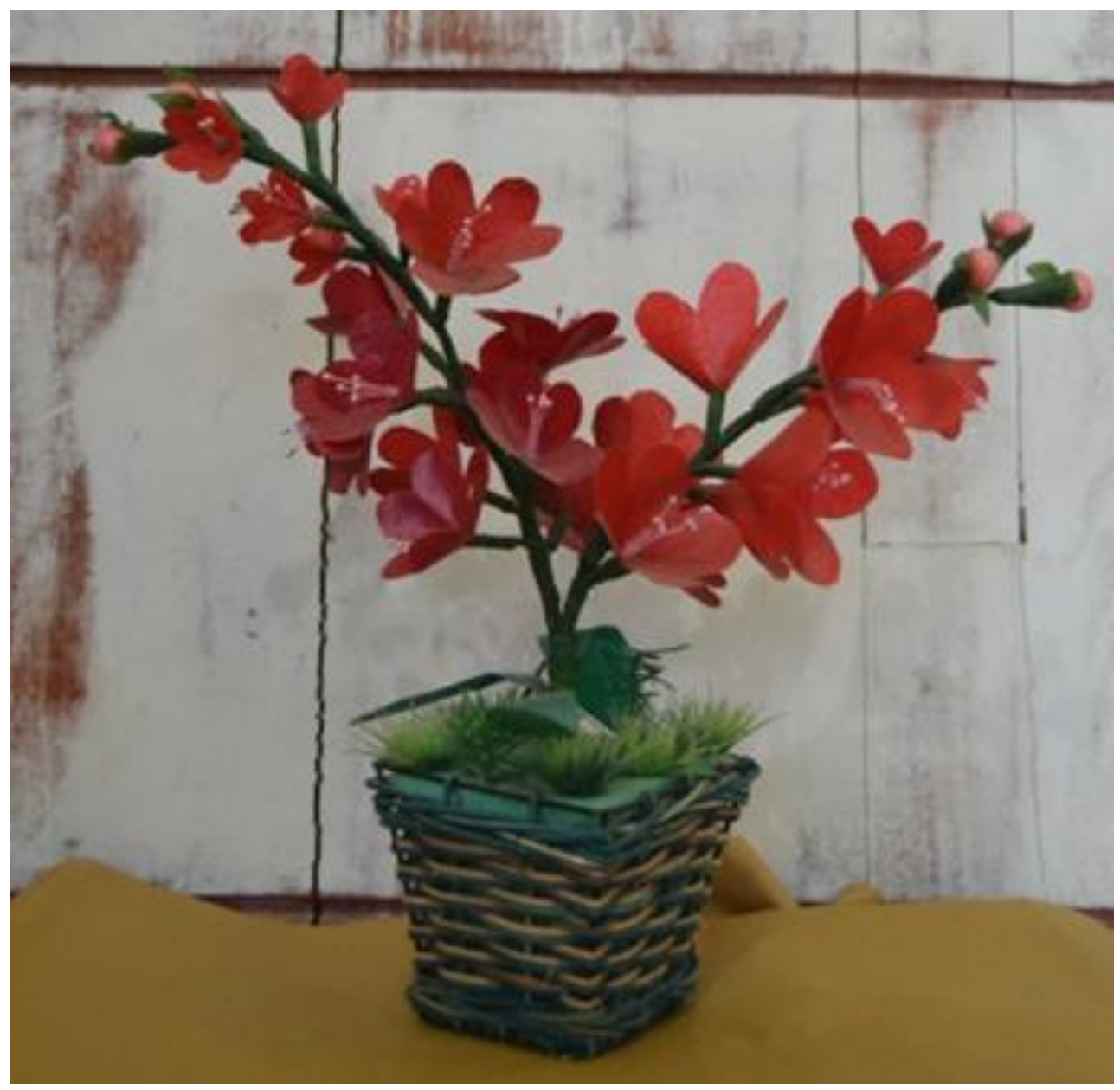

Gambar 2. Produk Bunga Plastik

Dari kegiatan ini, pengrajin santriwati yang telah dilatih memiliki kemampuan dalam menghasilkan produk bunga plastik dengan desain menggunakan bahan rotan dan plastik bekas. 


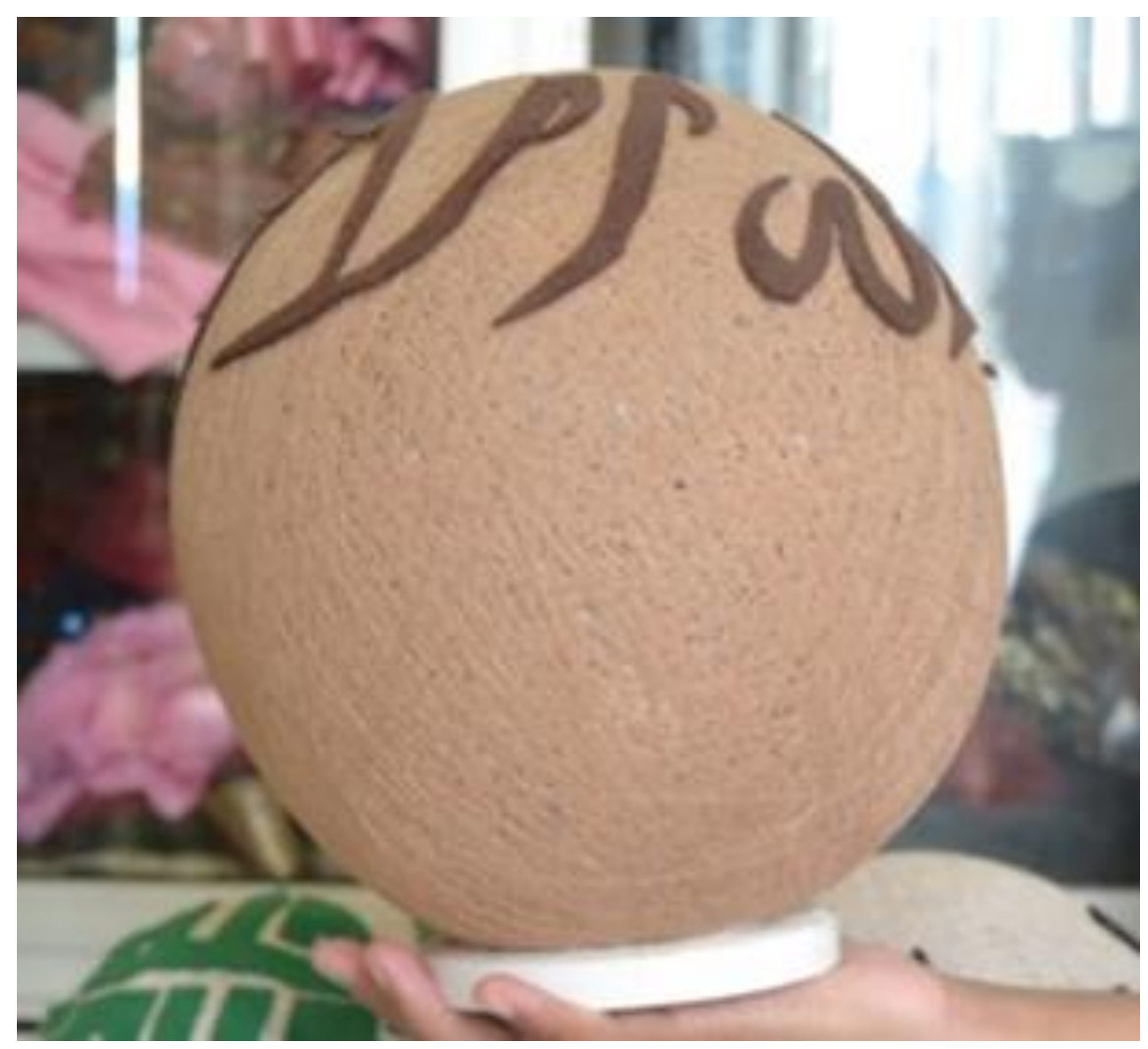

Gambar 3. Produk Lampion

Dari kegiatan ini, pengrajin santriwati yang telah dilatih memiliki kemampuan dalam menghasilkan produk lampion dengan desain Arabic 


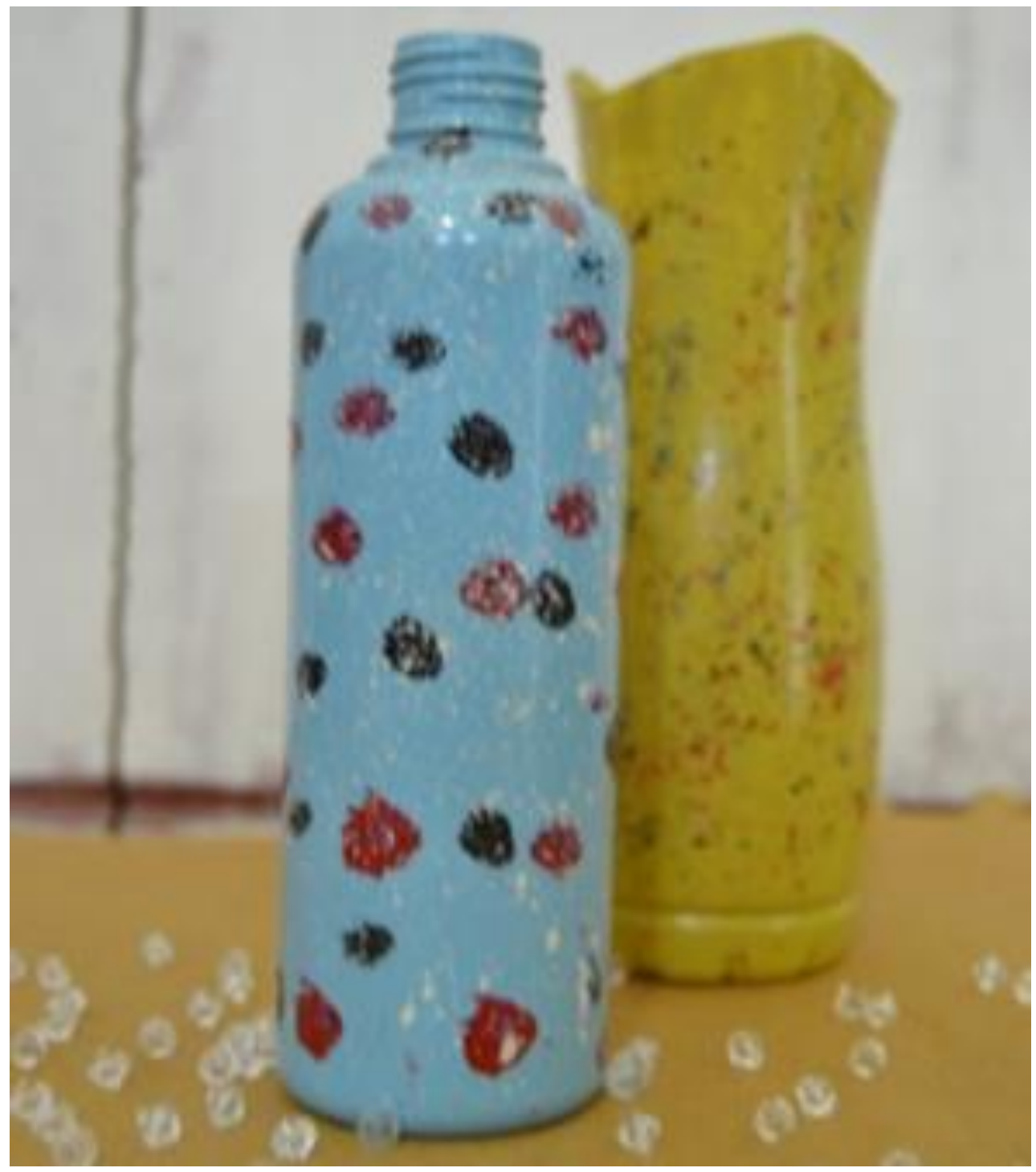

Gambar 4. Vas Bunga

Dari kegiatan ini, pengrajin santriwati yang telah dilatih memiliki kemampuan dalam menghasilkan produk Vas bunga dengan desain pulkadot yang memencar. 


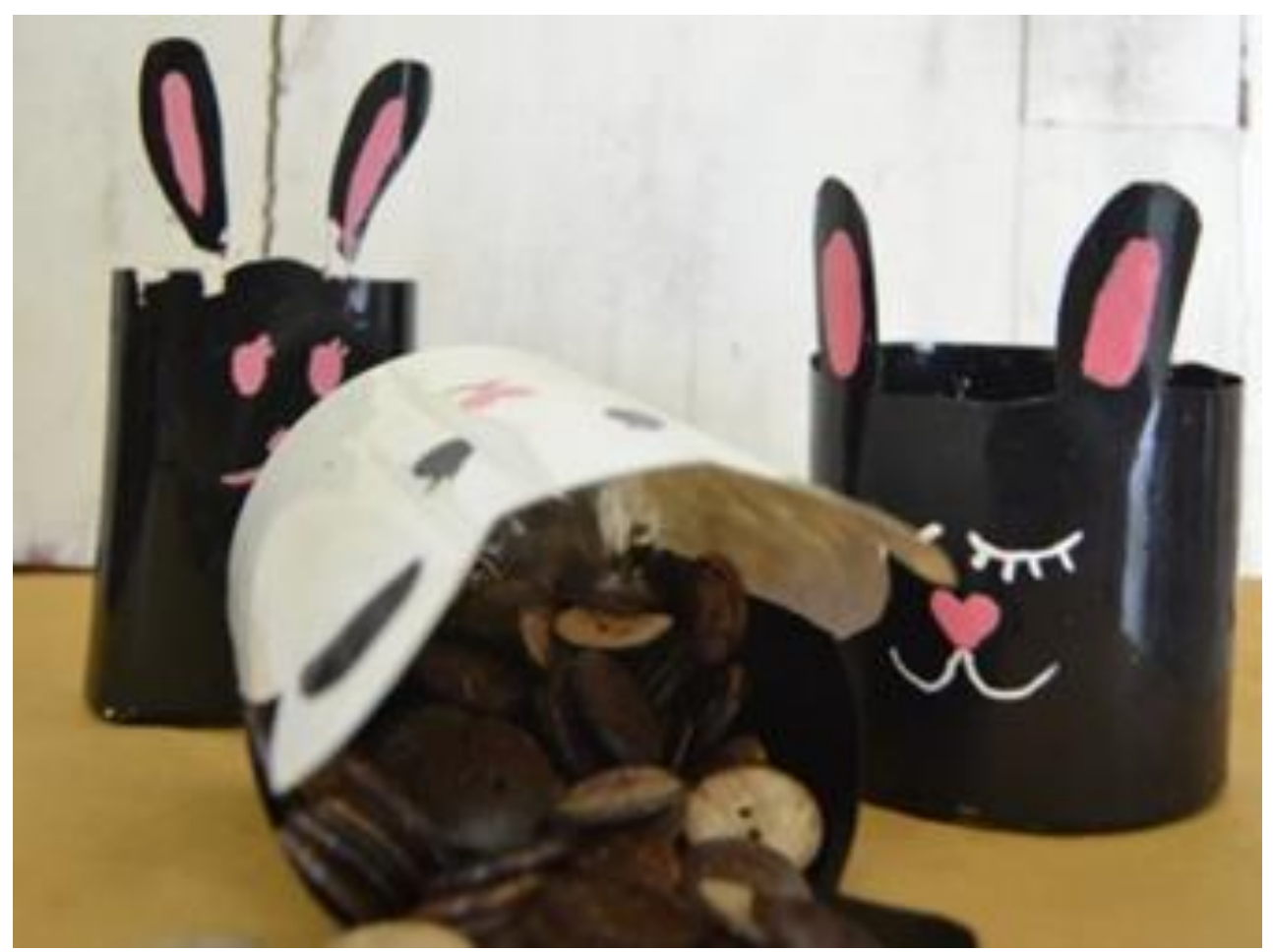

Gambar 5. Produk Hisan Kamar

Dari kegiatan ini, pengrajin santriwati yang telah dilatih memiliki kemampuan dalam menghasilkan produk hiasan kamar dengan desain bermotif kucing.

Dari beberapa kegiatan pengabdian terhadap kerajinan santri merupakan sebuah solusi terbaik bagi pengrajin yang mungkin membutuhkan potensi karya berkhas santri. Tepatnya pada hasil produk kerajinan di wilayah AzZainiyah Pondok Pesantren Nurul Jadid. Yang mana di samping itu, hendaknya seorang pengrajin dapat menggunakan hasil keterampilan karyanya, di pasarkan melalui online ataupun memasarkan secara lansung, sehingga menghasilkan suatu peluang besar dalam manajeman perekonomian dalam lingkup pesantren.

\section{b. Penerapan kewirausahaan di pesantren}

Pengembangan ekonomi kreatif Indonesia merupakan wujud optimisme serta luapan aspirasi untuk mendukung mewujudkan visi Indonesia yaitu menjadi negara yang maju. Didalamnya terdapat pemikiran, cita-cita, 
imajinasi, dan mimpi untuk menjadi masyarakat dengan kualitas hidup yang tinggi, sejahtera, dan kreatif.

Dalam ekonomi kreatif, SDM menjadi modal utama dalam sebuah pengembangan berawal dari gagasan, ide dan pemikiran, diharapkan SDM ini mampu menjadikan barang bernilai rendah menjadi barang yang bernilai tinggi dan berdaya jual. Profesi yang mengharuskan seseorang untuk memiliki daya kreativitas tinggi adalah wirausahawan. Maka pengembangan ekonomi kreatif ini secara tidak langsung mengarahkan dan mencoba untuk menciptakan wirausaha-wirausaha (entrepreneur) yang handal dalam bidangnya masing-masing. Daya kreativitas harus dilandasi oleh cara berpikir yang maju, penuh dengan gagasan-gagasan baru yang berbeda dengan produk yang sudah ada. Peluang pengembangan ekonomi kreatif telah merambah pada dunia pendidikan. Tidak luput juga dalam dunia pesantren. Banyak ditemukan pesantren-pesantren yang didalamnya menciptakan usaha bisnis (Suryana, 2013).

Pesantren adalah sebuah pendidikan tradisional yang para siswanya tinggal bersama dan belajar di bawah bimbingan guru yang lebih dikenal dengan sebutan kiai dan mempunyai asrama untuk tempat menginap santri. Santri tersebut berada dalam kompleks yang juga menyediakan masjid untuk beribadah, ruang untuk belajar, dan kegiatan keagamaan lainnya. Kompleks ini biasanya dikelilingi oleh tembok untuk dapat mengawasi keluar masuknya para santri sesuai dengan peraturan yang berlaku (Hoerniasih \& Nia, 2017).

Pesantren yang identik dengan ruh pendidikan Islam, yang identik pula didalamnya mengkaji tentang hukum-hukum Islam, kini telah berkembang mengikuti arus kontemporer dalam memberdayakan santri-santrinya. Peneliti mengangkat judul penelitian ini berangkat dari ketertarikan untuk memahami motivasi dan strategi apa yang dijadikan prinsip bagi suatu pesantren untuk mengembangkan ekonomi kreatif dilingkungannya (Noviyanti, 2017).

Dari hasil kerajinan kreatifitas santri yang telah di latih dengan mengadakan workshop pada hari rabu tanggal 10 februari 2021, perlu ada penerapan kewirausahaan dengan bekerja sama dengan $\mathrm{Nj}$ Mart (tempat pembelanjaan santri) sehingga hasil krajinan yang telah di buat oleh para santri yang telah di latih bisa menghasilkan uang dengan menejemen yang baik dalam memasarkan. Baik itu memasarkan hasil kerajinan dengan cara 
offline maupun online. Sehingga para santri bisa mengembangkan hasil kreatifitas santri dengan jiwa entrepreneur.

\section{Kesimpulan}

Berdasarkan hasil dari kegiatan pengabdian kepada Pondok Pesantren Nurul Jadid Karanganyar, Paiton Probolinggo. Disimpulkan hal-hal sebagai berikut:

a. Meningkatkan pengetahuan dan keterampilan para santri Pondok Pesantren Nurul Jadid Karanganyar, Paiton Probolinggo wilayah azzainiyah

b. Meningkatkan pengetahuan kewirausahaan bakat minat santri dalam upaya meningkatkan kemandirian santri sangat baik karena dapat meningkatkan motivasi berwirausaha yang selanjutnya akan meningkatkan kesejahteraan santri.

c. Meningkatkan pengetahuan kewirausahaan terhadap kesejahteraan santri dalam memacu kreativitas dan inovasi santri dalam mengembangkan minat dan bakat yang dapat dituangkan dalam kegiatan kewirausahaan.

\section{Pengakuan}

Alhamdulillah, Puji syukur atas terlaksananya proses pendampingan pemberdayaan hasil kreatifitas santri untuk meningkatkan perekonomian pesantren di masa pandemi covid 19 (studi pp. Nurul jadid wil. Az zainiyah), tim abdimas mengucapkan banyak terimakasih disampaikan kepada:

1. Lembaga Penerbitan, Penelitian dan Pengabdian kepada Masyarakat (LP3M) Universitas Nurul Jadid (UNUJA) yang telah memberikan dukungan baik secara material maupun non material.

2. Fakultas Agama Islam Universitas Nurul Jadid (UNUJA) yang telah memberi dukungan atas terselenggaranya kegiatan pengabdian kepada masyarakat ini.

3. Kepala Wilayah, Pengurus KOPIN, pengurus kantor kerajinanan wilayah azzainiyah, di lingkungan pondok pesantren nurul jadid wilayah Az-Zainiyah. 
4. Seluruh peserta dalam pelatihan, yaitu para santriwati di wilayah azzainiyah pondok pesantren nurul jadid yang antusias dalam mengikuti kegiatan ini.

\section{Referensi}

Anwar, C. M. (2021). KEGIATAN MENUMBUHKAN KREATIFITAS REMAJA DI YAYASAN PONDOK PESANTREN TUNAS INSAN MULIA SAWANGAN DEPOK. PENGABDIAN SOSIAL, 122-126.

Arikunto, S. (2010). Prosedur Penelitian Suatu Pendekatan Praktik. Jakarta: Rineka Cipta.

Fatmawati, V. W. (2019). SANTRI BERDIKARI: SEBUAH UPAYA MEWUJUDKAN SANTRI YANG SEHAT DAN MANDIRI. Empowering: Jurnal Pengabdian Masyarakat, 1-11.

Feriyadi, A. M. (2021). MENUMBUHKAN KREATIFITAS SANTRI DENGAN MEMBUAT MAKANAN KEKINIAN DI PONDOK PESANTREN DARUL FURQON RAMADHAN GUNUNG SINDUR BOGOR. PENGABDIAN SOSIAL, 133-138.

Hoerniasih, Nia. (2017). Penerapan Nilai-Nilai Agama Islam dalam Mengembangkan Pendidikan Kewirausahaan di Pondok Pesantren, Seminar nasional nonformal FKIP Universitas Bengkulu, Volume 1 No. $1: 1-14$

Kholiq, A. \&. (2021). Peningkatan Skill Santri Melalui Pemanfaatan Kain Bekas Menjadi Barang Bernilai Guna Berupa Keset di Pondok Pesantren Miftahul Mubtadiin Al-Ridlo Krempyang Tanjunganom Nganjuk. Janaka, Jurnal Pengabdian Masyarakat, 12-18.

Muda'i, S. \&. (2020). Pengembangan Bakat Dan Potensi Dakwah Santri Berbasis Teknologi Informasi Di masa Covid-19 Di Pondok Pesantren Putra-Putri Miftahul Mubtadiin Ar-Ridlo Krempyang Nganjuk. Janaka, Jurnal Pengabdian Masyarakat, 1-15. 
Noviyanti, R. 2017. "Peran Ekonomi Kreatif Terhadap Pengembangan Jiwa Entrepreneurship Di Lingkungan Pesantren: Studi Kasus di Pondok Modern Darussalam Gontor Putri I". Jurnal penelitian IImiah Intaj 1 (2), 250-262

Purwatiningsih, B \& Islam, R., (2017). Pengembangan Kreativitas Anak Asuh melalui Handycraft Panti Asuhan Al-Amin Geluran Taman Sidoarjo. Engagement: Jurnal Pengabdian Kepada Masyarakat, 1(1). 65-75

Rahmat. (2009). Penelitian Kualitatif. Equilibrum Vol 5 No. 9 : 1-8

Sari, M. M. (2021). MENUMBUHKAN EKONOMI KREATIF KERAJINAN TANGAN PADA BAHAN LOAK TERHADAP SANTRI AL-KAMILAH DI MASA PANDEMI. Jurnal Abdimas Tri Dharma Manajemen, 54-61.

Suryana, (2013) Ekonomi Kreatif (Ekonomi Baru : Mengubah Ide dan Menciptakan Peluang) Jakarta : Salemba Empat

Sugiyono, (2012). Metode Penelitian Kuantitatif, Kualitatif Dan R\&D. Bandung : Alfabeta

Sari, D. E., \& Wajdi, M. B. N., (2017). The Effectiveness Of The Method of GI With Electronic Workbench Study To Improve Activities and Results Student. Educatio: Journal of Education, 2(1), 136-150.

Yamin, M. (2013).Strategi dan Metode dalam Model Pembelajaran. Jakarta: Referensi (GP Press Group). 